\title{
Significance of variability in Turborotalita quinqueloba (Natland) test size and abundance for paleoceanographic interpretations in the Norwegian-Greenland Sea
}

\author{
Henning A. Bauch \\ GEOMAR, Research Center for Marine Geosciences, Wischhofstraße 1-3, 24148 Kiel, Germany
}

Received 30 January 1993; revision accepted 14 December 1993

\begin{abstract}
Biometric analyses on shells of Turborotalita quinqueloba (Natland) reflect the paleoceanographic conditions in the Norwegian-Greenland Sea (NGS). Both median and mean size variations exhibit a steady increase after the Last Glacial Maximum (LGM). After Termination I the size eventually reaches a constant level with only minor fluctuation. In contrast, peak abundances of specimens occur somewhat later, during the Holocene climatic optimum and rapidly decrease again in the youngest sediments. Test sizes are larger at the Vøring Plateau in the vicinity of incoming Atlantic water than in water further to the west. Turborotalita quinqueloba first appeared in the southwestern part of the NGS with a preliminary major peak in abundance and size well below the Younger Dryas. This species was present in sizes $<125 \mu \mathrm{m}$ in this area during almost entire oxygen isotopic Stage 2. This was not observed in the more easterly located cores.

It seems likely that size variations as a 'tool' for NGS paleoceanographic interpretations are not only valuable for the time since the LGM, but can also be applied to older isotopic stages where abundances of $T$. quinqueloba are low or absent in the $>125 \mu \mathrm{m}$ size-fractions but are high in the 63-125 $\mu \mathrm{m}$ fraction (e.g. Stages 7, 9 and 11 ).
\end{abstract}

\section{Introduction}

The modern surface waters of the NorwegianGreenland Sea (NGS) can be subdivided into three major hydrographic regimes (Fig. 1): The relatively cold and low saline water of the Polar Domain is restricted to the western part, whereas the Atlantic Domain is under strong influence of the warmer, nutrient-rich, and normal saline inflow of Atlantic water masses. In between lies the Arctic Domain, a 'mixing' of Arctic and Atlantic waters (Swift, 1986). The properties of these defined surface water masses are also expressed in the foraminiferal assemblages from surface sediments (Kellogg, 1976), where subpolar forms, e.g. Globigerina bulloides d'Orbigny, occur on the east- ern side, while a polar species [Neogloboquadrina pachyderma (Ehrenberg), sinistral] is widely spread in the remaining parts of the NGS.

The subpolar species Turborotalita quinqueloba (Natland) has proven to be in particular valuable for paleoceanographic interpretations because it is the most abundant and widespread of all subpolar foraminifera in the interglacial NGS and is almost ubiquitous in Holocene as well as Recent sediments (Bauch, 1993). In the modern ocean, specimens are found as far north as the southern Arctic Ocean (Carstens and Wefer, 1992). Therefore, this species is bound to reflect best the oceanographic changes that occurred after a pronounced glacial period when the influence of the Atlantic Water steadily began to affect NGS water circulation. 


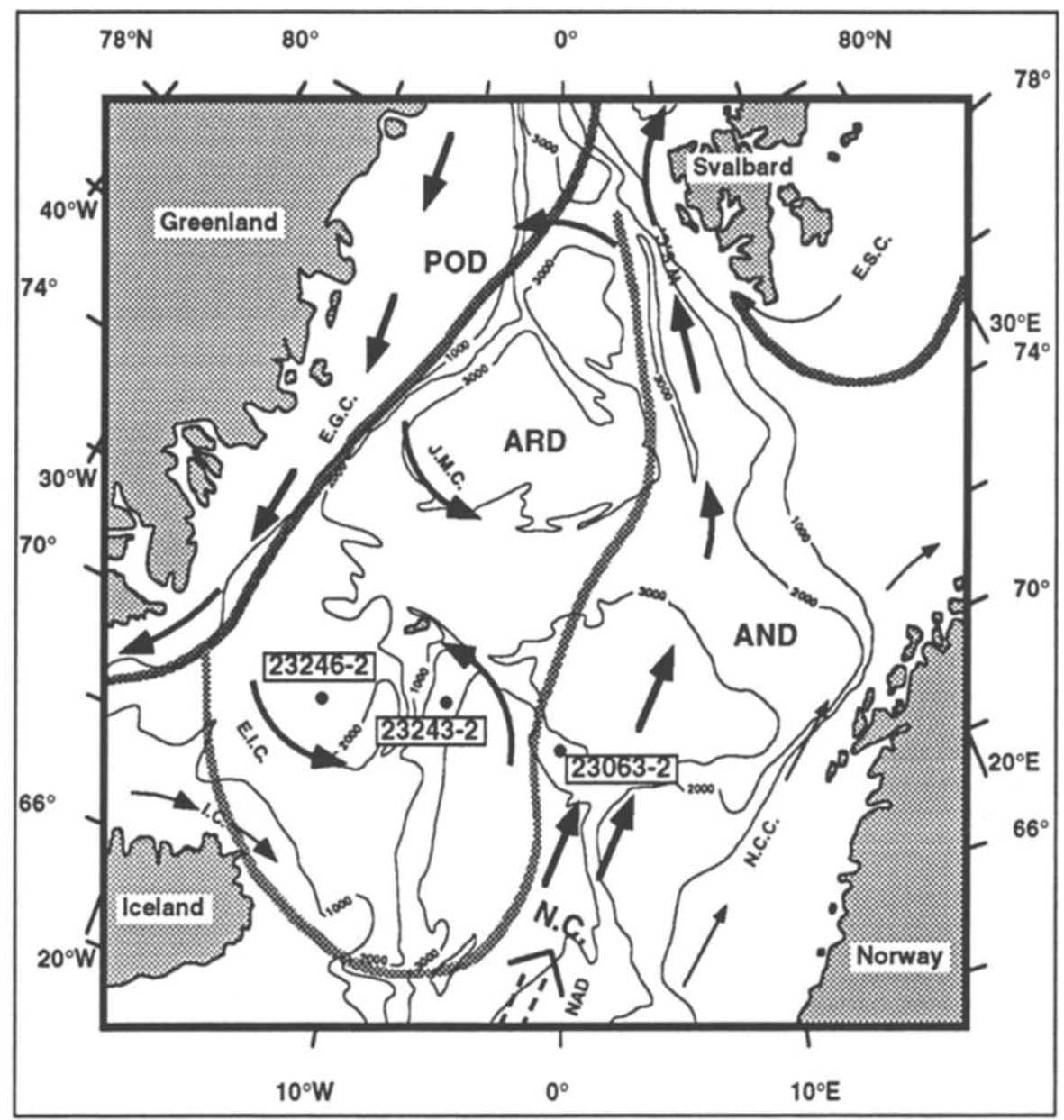

\section{Arctic Front}

\section{Polar Front}

Fig. 1. Surface water circulation and distribution of water masses in the studied area (after Swift, 1986) and position of investigated boxcores; $P O D=$ Polar Domain, $A R D=$ Arctic Domain, $A N D=$ Atlantic Domain.

Because T. quinqueloba bears symbionts its life habitat is mainly restricted to the photic zone (Bé, 1977; Hemleben et al., 1989). Size measurements for paleoceanographic use have been previously carried out on subpolar foraminifera before (Malmgren and Kennett, 1976, 1978a,b). These investigations were based on $G$. bulloides from southern Indian Ocean sediments. Although the oceanographic setting of the surface water circulation of this region is much more stable (Peterson and Stramma, 1991), the early results of Malmgren and Kennett (1978a) were very promising in showing a strong tie between glacial-interglacial changes and test size variability.

Kellogg (1984) noted the occurrence of smallsized tests $(<149 \mu \mathrm{m})$ of $T$. quinqueloba in sediment samples from the high latitude northern hemisphere where there were no specimens of this species in mesh sizes $>149 \mu \mathrm{m}$, but did not interpret the possible paleoceanographic meaning of these size changes.

At the onset of this study, high test concen- 
trations were observed in oxygen isotopic Stages 7,9 , and 11 , particularly within the mesh size $<125 \mu \mathrm{m}$ only, and in cores from the eastern part of the NGS (Bauch, 1993). These initial but still superficial biometrical observations led to a closer investigation of core material that covers the time period of a glacial-integlacial transition. These intervals are bound to reflect best the major changes in water circulation patterns that are indicative for a post-glacial warming (Broecker and Denton, 1989). The purpose of this study is (1) to reveal differences in foraminiferal test size as a significant feature in NGS sediments and (2) that this kind of approach is a profitable micropaleontological 'tool' independent from conventional quantitative microfaunal analyses; (3) how these results may integrate into a latest Quaternary paleoceanographic perspective and stratigraphy based on stable isotopes.

\section{Material and methods}

Three boxcores have been investigated along a transect ranging from the Norwegian Sea to the northern Iceland Plateau (Vøring PlateauKolbeinsey Ridge). These are from locations beneath different water mass regimes (Fig. 1) and contain sediments covering the climatic changes since the LGM.

These cores (Table 1) were collected from two sites during Cruise ARK II by the RV Polarstern (Augstein et al., 1984) and the third from a site during Cruise $2 / 2$ by the RV Meteor (Gerlach

Table 1

Geographical position and water depth of the investigated boxcores

\begin{tabular}{lcccc}
\hline Cruise & Core & Longitude & Latitude & $\begin{array}{l}\text { Water } \\
\text { depth }\end{array}$ \\
\hline $\begin{array}{l}\text { RV Meteor } 2 / 2 \\
\text { RV Polarstern } \\
\text { ARK II }\end{array}$ & $23063-2$ & $68^{\circ} 45.0^{\prime} \mathrm{N}$ & $00^{\circ} 00.0^{\prime} \mathrm{W}$ & $2302 \mathrm{~m}$ \\
$\begin{array}{l}\text { RV Polarstern } \\
\text { ARK II }\end{array}$ & $23243-2$ & $6^{\circ} 22.5^{\prime} \mathrm{N}$ & $06^{\circ} 32.4^{\prime} \mathrm{W}$ & $2716 \mathrm{~m}$ \\
\hline
\end{tabular}

Core numbers according to Geologisch-Pald̈ontologisches Institut, Kiel (GIK) et al., 1986). Although Cores 23246-2 and 23243-2 fall within the same oceanographic domain, Site 23246 is regarded here as 'polar water'-influenced because it does not contain $G$. bulloides in Holocene sediments as opposed to Site 23243. These two cores also contain a distinctive rhyolitic ash layer. South and west of core 23246-2 possibly the same stratigraphic event has been attributed to the Vedde Ash (Sejrup et al., 1989; Lackschewitz, 1991), which falls within the Younger Dryas Event (Mangerud et al., 1984) rendering this layer an important isochronous horizon for interpreting the $\delta^{18} \mathrm{O} /{ }^{13} \mathrm{C}$ isotopes. The stratigraphic framework for all three cores is based on stable isotopic data performed on Neogloboquadrina pachyderma sinistral which were originally undertaken by Vogelsang (1990). Vogelsang's interpretation has been slightly altered, especially with regard to the duration of the subdivided deglaciation, Termination $\mathrm{I}\left(\mathrm{I}_{\mathbf{A}}\right.$ and $\left.\mathbf{I}_{\mathbf{B}}\right)$. This event started $\sim 14,900$ yrs B.P. and terminated above the Younger Dryas at $\sim 9000$ yrs B.P. ${ }^{14} \mathrm{C}$ ages (Sarnthein et al., 1992).

Sampling of boxcores was carried out at a resolution of $1-2.5 \mathrm{~cm}$. In most cases, samples were originally taken as $1 \mathrm{~cm}$ slices that were dried and weighed, and later washed into $>63 \mu \mathrm{m}$ residues. These residues were then dry-sieved into $63-125 \mu \mathrm{m}, 125-250 \mu \mathrm{m}$, and $250-500 \mu \mathrm{m}$ size-fractions. For studying the planktic foraminiferal assemblages quantitatively, the size-fractions $125-250 \mu \mathrm{m}$ and $250-500 \mu \mathrm{m}$ were considered separately and each appropriate sample was then split down by means of a microsplitter. The counting of species was supported by the computerized counting-keyboard and program Focos (Weinholz, 1987) linked to an Atari computer. Test concentrations are expressed as specimens per gram dry bulk sediment.

Biometric analyses were carried out on the 63-500 $\mu \mathrm{m}$ size-fraction by measuring the largest diameter across the umbilical side of $T$. quinqueloba (Fig. 2) with the aid of a binocular microscope (magnification $\times 80$ ). The scale of the eyepiece enabled a $12.5 \mu \mathrm{m}$ size classification. Although other authors have used a more detailed technique, measuring, e.g. diameter of test plus individual chambers (Kroon et al., 1988), the method applied 


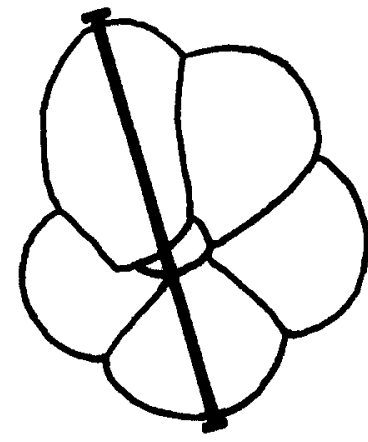

Fig. 2. Test of the subpolar foraminifer $T$. quinqueloba. Measurements were performed along the widest diameter across the umbilical side.

here was judged to be sufficient because of the compact test morphology of $T$. quinqueloba: An almost spherical circumference; low trochospirality; nearly constant number of chambers in the final whorl.

By far the most crucial point is how to obtain a small split sample that, in a statistical sense, still remains highly representative of the total sample. To achieve this goal, the original sample was split down to an appropriate small fraction by means of a conventional microsplitter. The split sample was filled into a small glass container (height: $3 \mathrm{~cm}$; opening diameter: $1.3 \mathrm{~cm}$ ). The container was then turned onto a wetted blueish surface containing a small grid (side length of each square: $0.4 \mathrm{~cm}$ ) for a higher relief of the individual foraminifer. In 'A' and ' $B$ ' of Fig. 3, the same sample is shown to test the evenness of the distribution using the method described above (measurement procedure started from left to right). It is obvious that the first 34 measured specimens (' $B$ ') are as evenly distributed as all 80 ('A'). Moreover, the mean average of ' $B$ ' deviates from ' $A$ ' by just $\sim 2 \%$. In contrast, ' $C$ ' is a sample that was spread directly from the microsplitter across the grid. Although it is equally well distributed as indicated by the low correlation coefficient, small specimens are clearly lacking here. Despite the fact that a relatively low number of 34 measurements per sample already yields representative results, a much higher total individual counts per sample was collected $(\sim 60-100)$. Overall, this method bears the advantage over previous studies
(Malmgren and Kennett, 1976; Kroon et al., 1988) in that the specimens were not randomly picked by vision.

A 'Notched Box-Plot' scheme wherein the box contains $50 \%$ of the data is used to express all measurements on a statistical basis (Fig. 4). This method is in particular useful for comparing nonGaussian distributions. If the lines (notches) parallel to the median do not overlap from the ones of neighbouring boxes one can be confident at about $95 \%$ level that the populations medians are different (Velleman and Hoaglin, 1981). In this study all size measurements are presented and discussed as mean and median values to reveal the differences in results between both methods.

\section{Results}

As shown in Fig. 5, variations in median test sizes show significant differences within, but not always throughout each core. Size variations are strongest in samples from the most easterly locality below Atlantic Water (Core 23063-2) and in Core 23243-2 from the eastern Iceland Plateau. The data from Core 23246-2 exhibit stronger changes in the deeper parts, but almost no differences above $16.5 \mathrm{~cm}$. Moreover, not only the size variability of T. quinqueloba is much more reduced within Core 23246-2 than within the other cores, the former also exhibits median test sizes that are generally lower reaching only up to $\sim 160 \mu \mathrm{m}$ as compared to, e.g., Core 23063-2 where peak median sizes are well above $200 \mu \mathrm{m}$.

Based on the resolution capacity of the binocular and the scale of the eyepieces ( $12.5 \mu \mathrm{m}$ intervals), the result of each sample was subdivided into its smallest possible size classes. Accordingly, size classes can be viewed as histograms (Fig. 6). Size distributions show various shapes ranging from unimodal, bimodal, to Gaussian and may reflect some sorting due to winnowing. In the samples towards the bottom of all cores the shapes of the histograms become more difficult to classify due to diminishing numbers of available specimens. In some of these deeper samples the size distribution is truncated by the limitation of the $63 \mu \mathrm{m}$ mesh.

Mean sizes show in comparison to the median results only negligible differences (Fig. 7). The 


\section{3-2}

Sample $(1,25 \mathrm{~cm})$

A

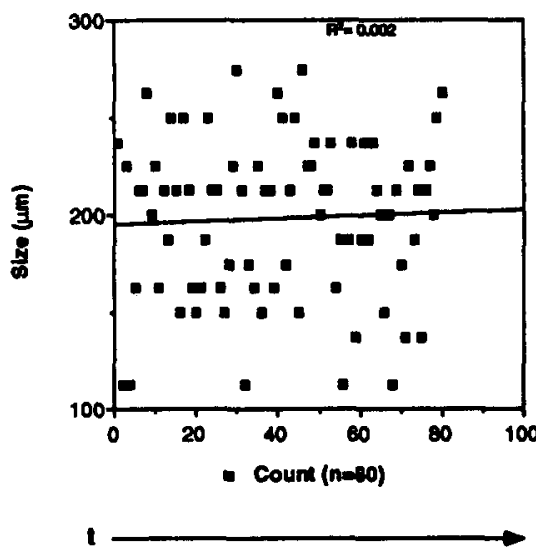

B

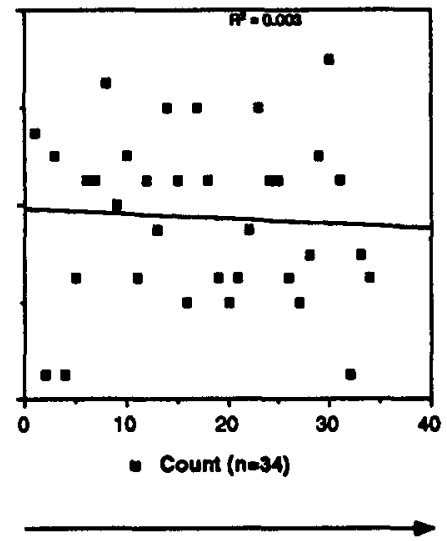

C

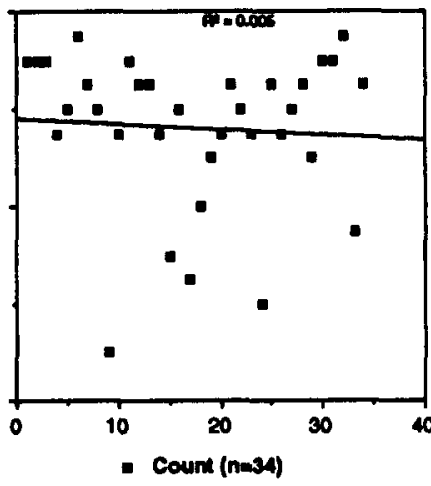

Fig. 3. Two differently prepared sets of split samples ('A, B' and 'C') from the same depth $(1.25 \mathrm{~cm})$ of Core $23063-2$ in which samples ' $A$ ' and 'B' show an even size distribution of tests, whereas sample ' $C$ ' lacks smaller tests; $t=$ time when measuring procedure started.

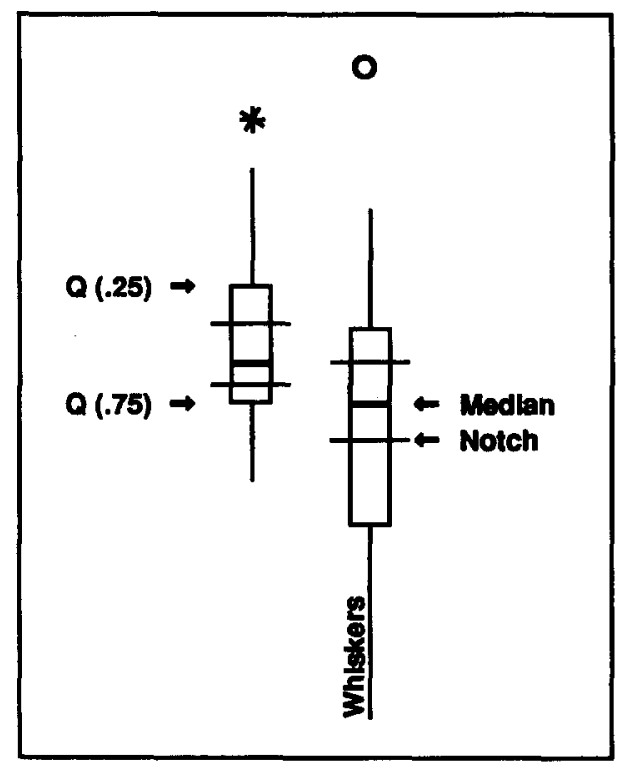

Fig. 4. The 'Notched Box-Plot' schemes enable comparisons of data sets on a statistical basis. $Q$, a quartile, marks each end of the box which contains $50 \%$ of the data; stars represent outside values and open circles far outside values. overall downcore pattern sustains in both data sets and proves a likewise good usability despite the various shapes in size distributions.

Both median and mean size variations exhibit an increase after the LGM (Substage 2.22) which correlates remarkably well with fluctuations of the oxygen isotopic curve during Termination I (Fig. 7). Mean sizes range up to about $180 \mu \mathrm{m}$ in Core 23243-2 and 23063-2 at the end of Termination I. Core $23246-2$ is marked by a rapid increase up to highest peak mean sizes $(\sim 170 \mu \mathrm{m})$ followed by an intermittent slight drop and eventually a mean size of about $160 \mu \mathrm{m}$ at the end of Termination I. During the later Holocene sizes do show some variations. But these are of much lesser degree than during the deglaciation phase, particularly in Cores 23243-2 and 23246-2.

Test concentrations of $T$. quinqueloba are highest in Core 23243-2 and together with the other two cores reveal the widespread distribution of this species in the NGS: In all cores peak abundances nearly coincide with lightest values of $\delta^{18} \mathrm{O}$ where the latter appear to be free from meltwater as documented by an increase in $\delta^{13} \mathrm{C}$ (deduced from 

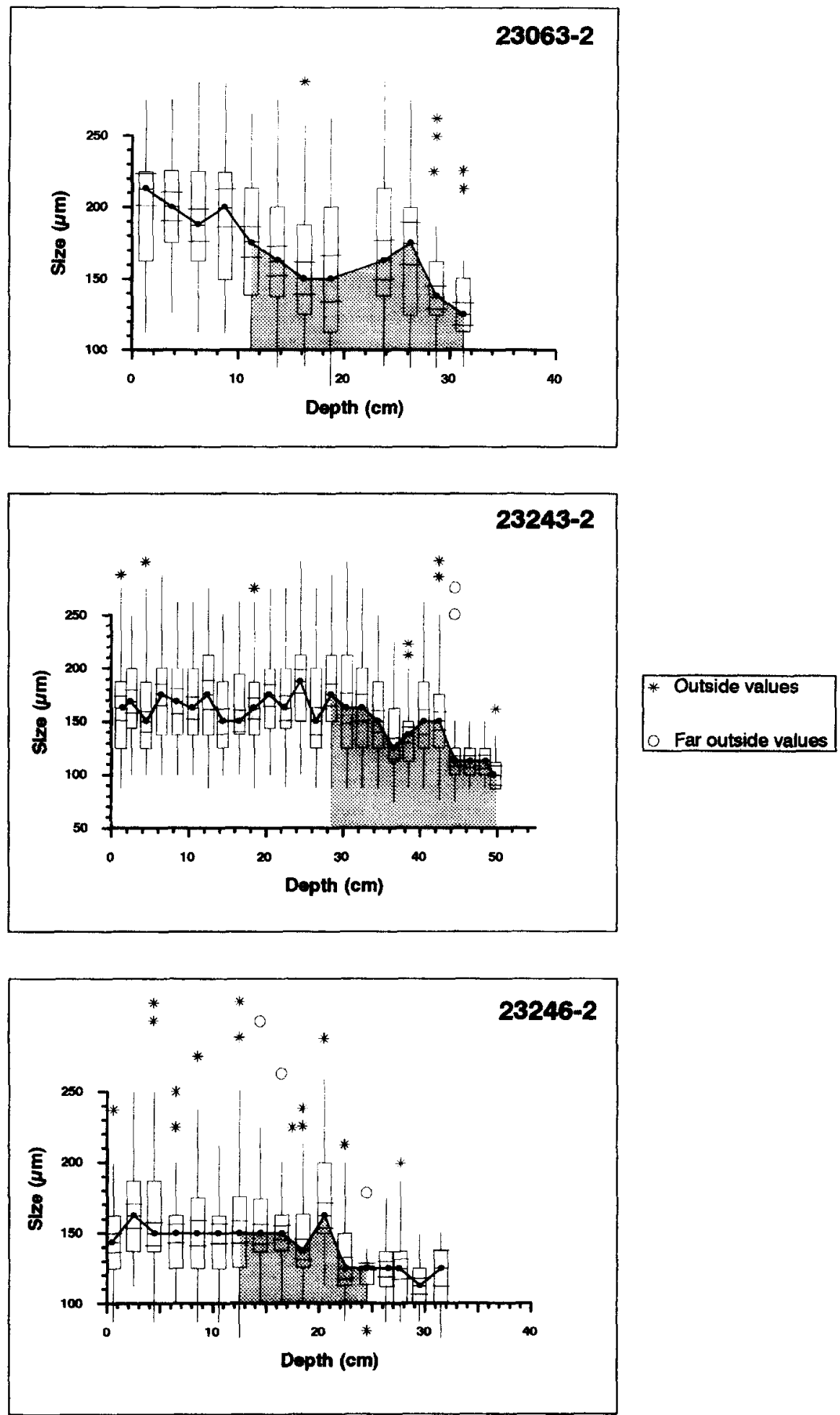

Fig. 5. 'Notched Box-Plots' reveal differences in median size of $T$. quinqueloba in each core. The position of notches of neighbouring boxes often overlap, but are 'significantly' different between e.g., the glacial and the Holocene times within each core (note the different vertical scale); shaded area marks Termination I. 


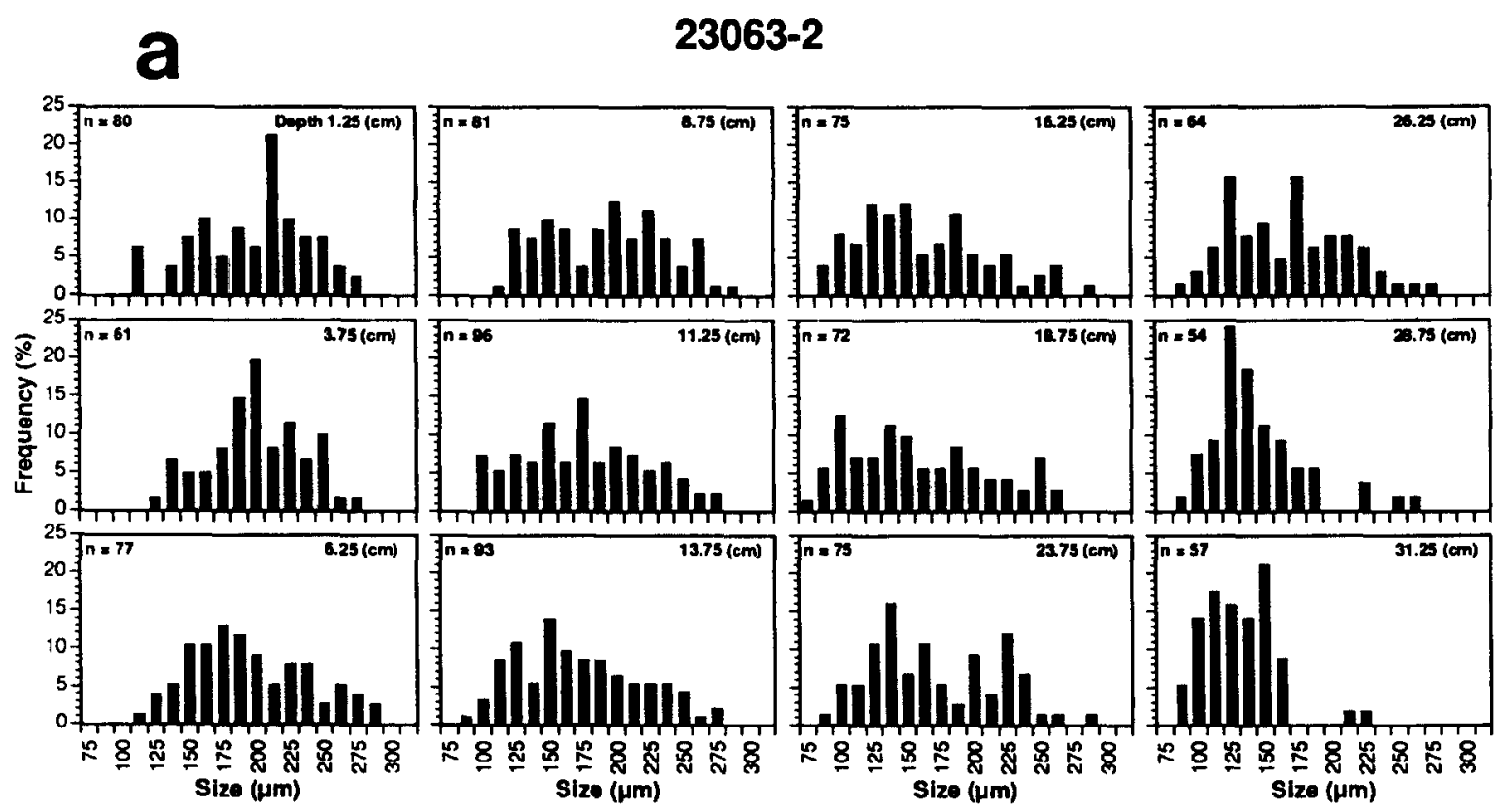

Fig. 6. Distribution of all measurements in percentage according to $12.5 \mu \mathrm{m}$ size classes. The size distribution of each sample exhibits various shapes ranging from unimodal and/or bimodal to gaussian.

other cores, the age of these peaks are estimated to be $\sim 6000$ yrs B.P.). A likewise good correlation of these peaks is not apparent when comparing test concentrations and test sizes.

In Cores 23246-2 and 23243-2 light $\delta^{18} \mathrm{O} /{ }^{13} \mathrm{C}$ isotopes reveal that the stratigraphic position of the Vedde Ash layer is just below a major meltwater spike. But although in Core 23243-2 test concentrations reach almost zero, $T$. quinqueloba still makes up $25 \%$ of the total assemblage in Core 23246-2 at the same core level as well as reaching largest test sizes below the ash. In fact, this species is definitely present with smaller tests during Substage 2.22.

Core 23246-2 continues down to a depth of $40.5 \mathrm{~cm}$ and Core $23063-2$ down to $34 \mathrm{~cm}$. In contrast Core 23243-2 is shown in its entire recovered length. In Fig. 7 only those samples with $T$. quinqueloba are shown. Below the listed samples there are no further signs of $T$. quinqueloba. In the case of Core 23243-2 this fact was corroborated by precisely linking it by means of the ash layer to the long gravity core 23243-1 from the same geographical position.
Intriguingly, towards the base of Core 23246-2 $(\sim 30 \mathrm{~cm})$ the epifaunal benthic foraminifer Cibicidoides wuellerstorfi (Schwager), a truly interglacial species in the NGS (Haake and Pflaumann, 1989; Ness, 1989; Struck, 1992), was observed. This fact most likely points here to Substage 2.3 (Weinelt, 1993). The correct stratigraphical assignment of Substage 2.22 is primarly based on oxygen isotopes but is additionally supported by the presence of the benthic foraminifer Siphotextularia rolshauseni Phleger and Parker. During the past at least 40,000 years this infaunal species was restricted to Stage 2 and has proven its stratigraphical usefulness as a faunal indicator for this time period (Struck and Ness, 1991; Struck, 1992).

A more detailed stratigraphic control of Termination I is not easily achieved in Core 23063-2, because this core lacks the Vedde Ash and has been sampled at comparatively large intervals $(2.5 \mathrm{~cm})$. In addition, there is good evidence that a large amount of Recent sediments is missing due to late Holocene erosion. This assumption is indicated by the unusual position of the main peak of test abundances and test sizes in 


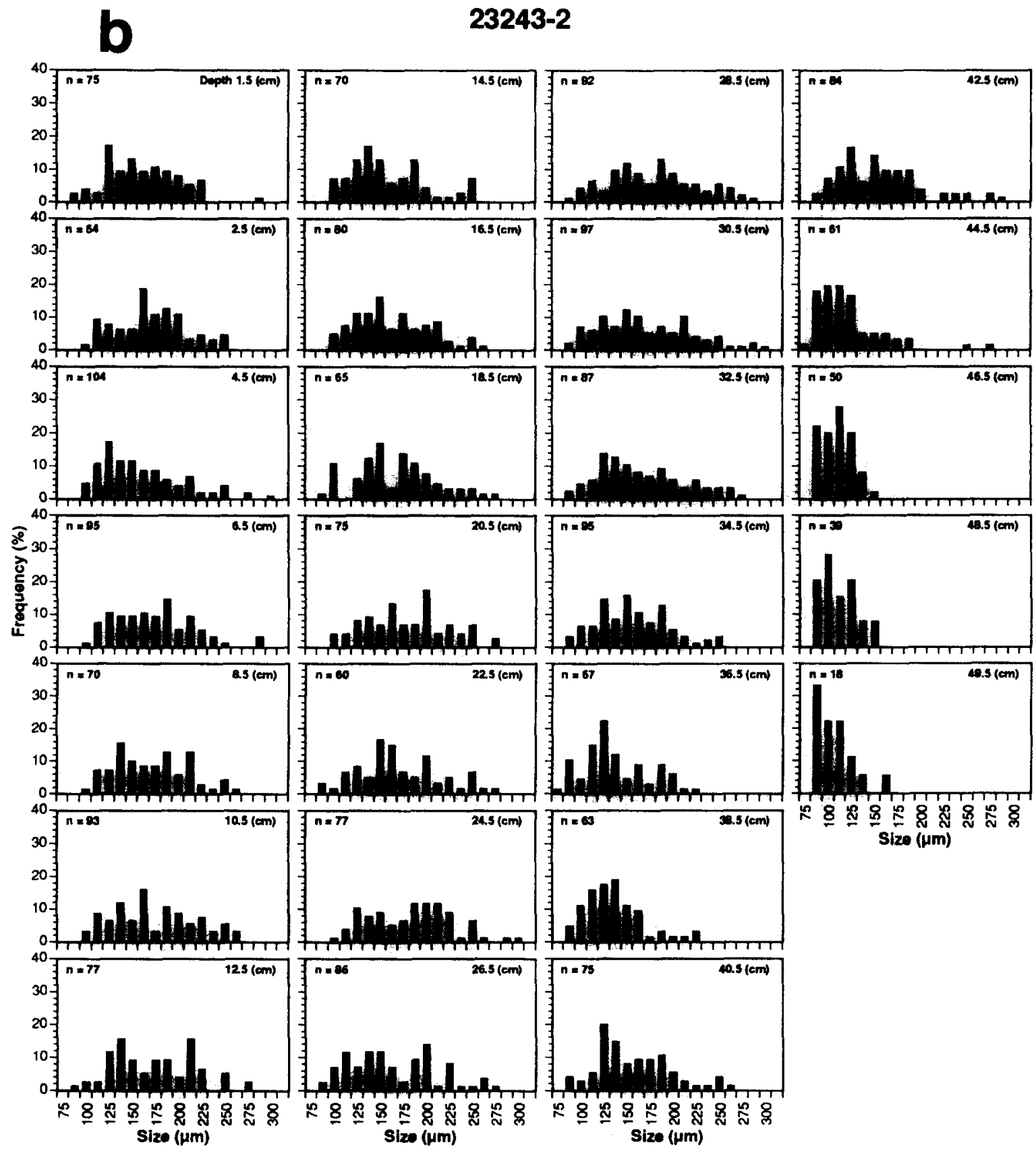

Fig. 6. (continued.)

conjunction with the corresponding light $\delta^{18} \mathrm{O}$ values close to the top of this core. The top sediment of Core 23243-2 is considered being the youngest of all three investigated cores.

\section{Discussion and conelusion}

The investigation has revealed that subpolar foraminifer $T$. quinqueloba increases in size during 


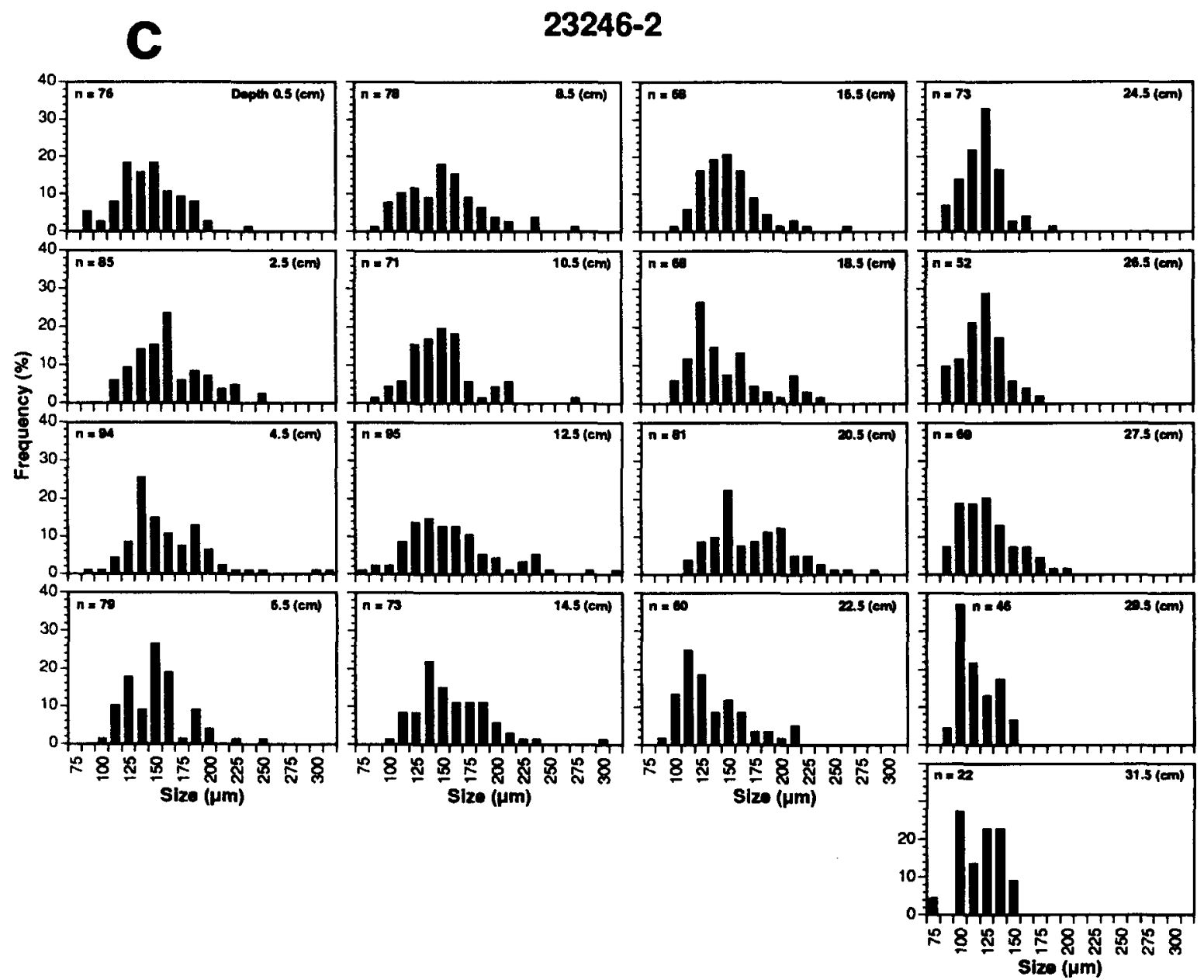

Termination I. Sizes are much larger in the vicinity of incoming Atlantic Water even though maximum test concentrations are found in the Arctic Domain (Core 23243-2). In the Malmgren and Kennett (1978a,b) studies based on the likewise subpolar form $G$. bulloides, these authors identified a good correlation between peak interglacial conditions and test sizes, i.e. sizes are largest in the optimum environment, depending upon the hydrographic regime of the particular core position. Their observed time lag may be caused in part by the effect of calcium carbonate dissolution resulting from highly corrosive waters leading to a dissolution of smaller tests and hence, to a bias of larger specimens during glacial periods. In a later study, Malmgren (1985) resumed that corrosion does not lead to observable differences in mean test sizes of various recent species. My preliminary observations on interglacial core material from the Rockall area west of Ireland to the NGS, however, agree to above findings in that the 'warmer' subpolar species e.g., G. bulloides and Globorotalia inflata (d'Orbigny), undoubtedly decrease in size towards higher latitudes. A strong tie between size and surface water temperature appears to be a logical cause.

In the NGS, it is not yet possible to identify a major ecological factor to explain the size variability e.g., whether it is related to temperature, salinity or nutrients. Clearly, the E-W decrease towards smaller sizes of $T$. quinqueloba somehow reflects the specific oceanic character of each site. In the 

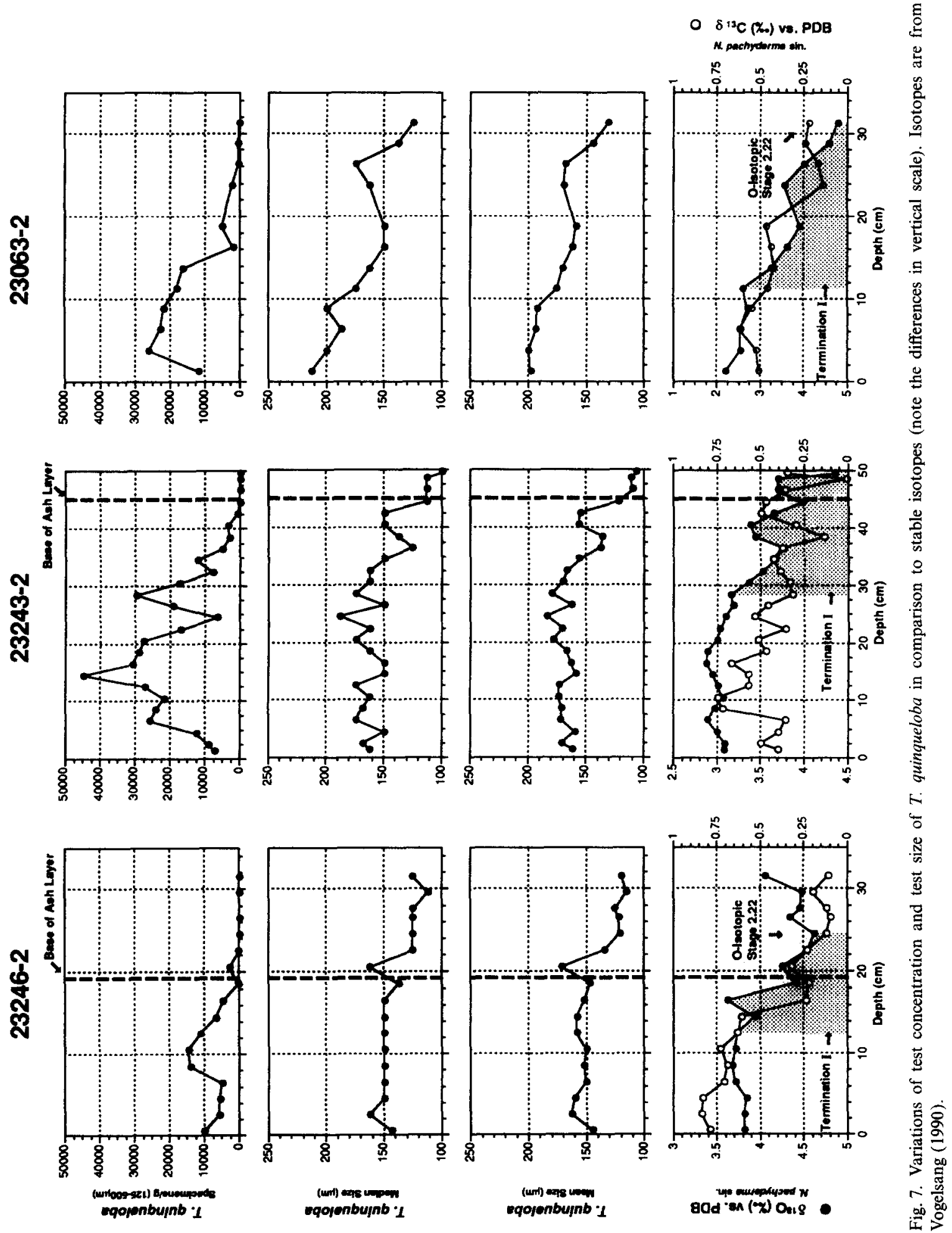
modern NGS, temperature as well as salinity also show a westerly decreasing tendency away from the Norwegian Current (Dietrich, 1969; Swift, 1986). Moreover, Hecht (1976) concluded that maximum test sizes of warmer water species of planktic foraminifera correspond to optimum environmental conditions.

The sole fact that this subpolar species is present at all during Stage 2, although in small sizes, precludes (1) size-dependent selective dissolution (Berger, 1968). This is corrorborated because (2) even smallest tests are often translucent and do not show signs of significant corrosion; (3) both eastern cores are from greater water depth than Core 23246-2. Therefore, during Stage 2 and early Termination I (Termination $\mathbf{I}_{\mathbf{A}}$ ) conditions appear to have been more favourable for $T$. quinqueloba, first in the western part of the NGS. This was possibly due to the influence of Atlantic Water that may have led to the transportation of smallsized specimens - many of them were most likely at pre-adult stages. The scenario would have been similar to the modern situation of the southern Nansen Basin, north of Svalbard. There, smallsized tests of $T$. quinqueloba are seen in the water column despite polar conditions and ice cover. These finds are interpreted as being the result from transportation by the West Spitsbergen Current (Carstens and Wefer, 1992). The weak but notable inflow of some Atlantic water onto the western Iceland Plateau during Stage 2 possibly induced bottom currents, and in this way was also responsible for the presence of $C$. wuellerstorfi at a time when this species is usually not encountered in other areas of the NGS (Struck, 1992).

In contrast to the early finds of $T$. quinqueloba in the west, subpolar planktic foraminifera occur in southeastern NGS after 13,000 yrs B.P., at the end of Termination $I_{A}$ (Jansen and Bjørklund, 1986).

Size distributions within Cores 23246-2 and 23063-2 are nevertheless very similar after Substage 2.22. Both cores show a rapid size increase shortly afterwards, but this species is still present in rather low abundances. Correlating the Vedde Ash and microfaunal results of Core 23246-2 with the data in Core 23063-2 would tentatively place the Younger Dryas Event for the latter somewhere between 19 and $24 \mathrm{~cm}$. In contrast, Core 23243-2 lacks this prominent size increase below the Younger Dryas, indicating that this part of the NGS was less affected by Atlantic influence even though open-ocean circulation has been proposed for this time period (Veum et al., 1992). Above the ash layer, the rapid increase in size also suggests a growing input of Atlantic Water with another ensuing slight drop until oceanographic conditions were firmly established afterwards. This marked decrease in size in Core 23243-2 falls within Termination $I_{B}$ and is also accompanied by heavy $\delta^{18} \mathrm{O}$-values. This decrease of the latter has been noted before and interpreted as fluctuations in ocean heat flux resulting from an actual change of atmospheric temperatures (Dansgaard et al., 1989; Lehman and Keigwin, 1992; Koç-Karpuz and Jansen, 1992).

Despite the lack of oxygen isotopic events and absolute ages, it is still possible to interpret the climatic evolution of the later Holocene, after Termination I. If the assumption is correct that the highest test concentrations of $T$. quinqueloba represent the climatic optimum, then the evolution of the planktic foraminiferal record is in accordance with that of other planktic microfossils, e.g. coccoliths and dinoflagellate cysts (Baumann and Mathiessen, 1992). Sizes remain rather constant over this interval and if they are indeed temperature-controlled, are consistent with the scenario of rather constant surface temperatures based on studies of NGS diatoms (Koç-Karpuz and Jansen, 1992). Nevertheless, the strong discrepancy between these constant sizes and the corresponding steady decrease in abundances of $T$. quinqueloba as seen in Core 23243-2 indicates that test size and abundances are possibly due to different mechanisms. This is additionally supported by the fact that largest Holocene test sizes are found in Core 23063-2 and not in Core 23243-2 which shows the highest abundances.

Test size variations of the subpolar planktic foraminifer $T$. quinqueloba are likely to open up a new tool for paleoceanographic interpretations of the NGS, which is independent from conventional quantitative methods such as faunal diversity. Size variations in $T$. quinqueloba are useful for the time interval since the LGM. The method is equally 
applicable to Termination II as well as those interglacial stages where numbers of specimens are strongly reduced in the larger mesh sizes (e.g., $>125 \mu \mathrm{m}$ ). Furthermore, because the presence of subpolar species appears to be indicative for the intrusion of Atlantic water into the NGS, then there should be no restriction in terms of the use of smaller mesh sizes. The main abundances of $T$. quinqueloba also occur in size classes $<149 \mu \mathrm{m}$. As a consequence, in a study such as CLIMAP (CLIMAP Project Members, 1976) most of them would not have been accounted for. Therefore, the importance of including certain small-sized planktic foraminifera into high-latitude paleoceanographic interpretations cannot be underemphasized.

\section{Acknowledgements}

Thanks are expressed to Jens Mathiessen and Peter Goldschmidt (Kiel) for reading an earlier manuscript of this paper. I am also indebted to Mike Kaminski (London) who provided useful comments which were gratefully appreciated. This study was financed by the Deutsche Forschungsgemeinschaft (DFG) and is contribution No. 184 of the Sonderforschungsbereich 313 at Kiel University.

\section{References}

Augstein, E., Hempel, G., Schwarz, J. and Thiede, J., 1984. Die Expedition Arktis II des FS 'Polarstern' 1984 mit Beitrāgen des FS 'Valdivia' und des Forschungsflugzeuges 'Falcon 20' zum Marginal Ice Zone Experiment 1984 (MIZEX). Ber. Polarforschung, 20, 192 pp.

Bauch, H.A., 1993. Planktische Foraminiferen im Europäischen Nordmeer - ihre Bedeutung für die paläo-ozeanographische Interpretation während der letzten 600.000 Jahre. Ber. Sonderforschungsbereich $313,40,108 \mathrm{pp}$.

Baumann, K.-H. and Matthiessen, J., 1992. Variations in surface water mass conditions in the Norwegian Sea: Evidence from Holocene coccolith and dinoflagellate cyst assemblages. Mar. Micropaleontol., 20: 129-146.

Bé, A.W., 1977. An ecological, zoogeographic and taxonomic review of recent planktonic foraminifera. In: A.T.S. Ramsey (Editor), Oceanic Micropaleontology. Academic Press, London, pp. 1-100.
Berger, W.H., 1968. Selective solutions and paleoclimatic interpretations. Deep-Sea Res., 15: 31-43.

Carstens, J. and Wefer, G., 1992. Recent distribution of planktonic foraminifera in the Nansen Basin, Arctic Ocean. Deep-Sea Res., 39(Suppl. 2): S507-S524.

CLIMAP Projekt Members, 1976. The surface of the ice-age earths. Science, 191: 1131-1137.

Dansgaard, W., White, J.W.C. and Johnson, S.J., 1989. The abrupt termination of the Younger Dryas climate event. Nature, 339: 532-533.

Dietrich, G., 1969. Atlas of the Hydrography of the Northern North Atlantic Ocean. Cons. Int. Explot. Mer, 140 pp.

Gerlach, S.A., Thiede, J., Graf, G. and Werner, F., 1986. Forschungsschiff Meteor, Reise 2 vom 19.6.-16.7.1986. Ber. Sonderforschungsbereich 313, Univ. Kiel., 4, 140 pp.

Haake, F.W. and Pflaumann, U., 1989. Late Pleistocene foraminiferal stratigraphy on the Vøring Plateau, Norwegian Sea. Boreas, 18: 343-356.

Hecht, A.D., 1976. An ecologic model for test size variation in Recent planktonic foraminifera, application to the fossil record. J. Foraminiferal Res., 6: 295-311.

Hemleben, C., Spindler, M. and Anderson, O.R., 1989. Modern Planktonic Foraminifera. Springer, New York, 363 pp.

Jansen, E. and Bjørklund, K.R., 1985. Surface ocean circulation in the Norwegian Sea, 15,000 B.P. to Present. Boreas, 14: 243-257.

Kellogg, T.B., 1984. Paleoclimatic significance of subpolar foraminifera in high-latitude marine sediments. Can. J. Earth Sci., 21: 189-193.

Koç-Karpuz, N. and Jansen, E., 1992. A high-resolution diatom record of the last deglaciation from the SE Norwegian Sea: Documentation of rapid climatic changes. Paleoceanography, 7: 499-520.

Kroon, D., Wouters, P., Moodley, L., Ganssen, G. and Troelstra, S.R., 1988. Phenotypic variation of Turborotalita quinqueloba (Natland) tests in living populations and in the Pleistocene of an eastern Mediterranean piston core. In: G.J.A. Brummer and D. Kroon (Editors), Planktonic Foraminifers as Tracers of Ocean-Climate History. Free Univ. Press, Amsterdam, pp. 131-143.

Lackschewitz, K.S., 1991. Sedimentation am aktiven mittelozeanischen Kolbeinsey Rücken (Nordisland)-Vulkanisch und klimatisch gesteuerte Ablagerungsprozesse im Spätquartär. Geomar Rep., Univ. Kiel, 9: 1-135.

Lehman, S.J. and Keigwin, L.D., 1992. High resolution record of the North Atlantic drift 14-8 kyr BP: Implications for climate, circulation, and ice sheet melting. Nature, 356: 757-762.

Malmgren, B.A., 1985. Dissolution effects on size distribution of recent planktonic foraminiferal species, South Atlantic Ocean. In: K.J. Hsü and H.J. Weissert (Editors), South Atlantic Paleoceanography. Cambridge Univ. Press, pp. 11-23.

Malmgren, B.A. and Kennett, J.P., 1976. Biometric analysis of phenotypic variation in Recent Globigerina bulloides d'Orbigny in the southern Indian Ocean. Mar. Micropaleontol., 1: 3-25. 
Malmgren, B.A. and Kennett, J.P., 1978a. Test size variations in Globigerina bulloides in response to Quaternary palaeoceanographic changes. Nature, 275: 123-124.

Malmgren, B.A. and Kennett, J.P., 1978b. Late Quaternary paleoclimatic applications of mean size variations in Globigerina bulloides d'Orbigny in the southern Indian Ocean. J. Paleontol., 52: 1195-1207.

Mangerud, J., Lies, S.E., Furnes, H., Kristiansen, I.L. and Lømo, L., 1984. Younger Dryas ash bed in Western Norway, with possible correlations to the Norwegian Sea and the North Atlantic. Quat. Res., 21: 85-104.

Nees, S., 1989. Biostratigraphie mit benthischen Foraminiferen im Europäischen Nordmeer für die letzten 350.000 Jahre. M.Sc. Thesis, Geol. Paläontol. Inst., Univ. München, 42 pp.

Peterson, R.G. and Stramma, I., 1991. Upper-level circulation in the South Atlantic Ocean. Prog. Oceanogr., 26: 1-73.

Sarnthein, M., Jansen, E., Arnold, M., Duplessy, J.C., Erlenkeuser, H., Flatoy, A., Weinelt, M., Veum, T. and Vogelsang, E., 1992. $\delta^{18} \mathrm{O}$ time-slice reconstructions of meltwater anomalies at Termination $I$ in the North Atlantic between 50 and $80^{\circ} \mathrm{N}$. In: E. Bard and W.S. Broecker (Editors), The Last Deglaciations. Kluwer, Dordrecht, pp. 183-200.

Sejrup, H.P., Sjoholm, J., Furnes, H., Beyer, I., Eide, L., Jansen, E. and Mangerud, J., 1989. Quaternary tephra chronology on the Iceland Plateau, north of Iceland. J. Quat. Sci., 4: 109-114.
Struck, U., 1992. Zur Paläo-Ökologie benthischer Foraminiferen im Europäischen Nordmeer während der letzten 600.000 Jahre. Ber. Sonderforschungsbereich 313, Univ. Kiel, 38, 89 pp.

Struck, U. and Nees, S., 1991. Die stratigraphische Verbreitung von Siphotextularia rolshauseni (Phleger and Parker) in Sedimentkernen aus dem Europäischen Nordmeer. Geol. Jahrb., Reihe A, 128: 243-249.

Swift, J.H., 1986. The Arctic Waters. In: B.G. Hurdle (Editor), The Nordic Seas. Springer, New York, pp. 129-151.

Velleman, P.F. and Hoaglin, D.C., 1981. Applications, Basics and Computing of Exploratory Data Analysis. Duxbury Press, Boston, $347 \mathrm{pp}$.

Veum, T., Jansen, E., Arnold, M., Beyer, I. and Duplessy, J.-C., 1992. Water mass exchange between the North Atlantic and the Norwegian Sea during the past 28,000 years. Nature, 356: 783-785.

Vogelsang, E., 1990. Paläo-Ozeanographie des Europäischen Nordmeeres anhand stabiler Kohlenstoff- und Sauerstoffisotope. Ber. Sonderforschungsbereich 313, Univ. Kiel., 23, 137 pp.

Weinelt, M., 1993. Veränderungen der Oberflächenzirkulation im Europäischen Nordmeer während der letzten 60.000 Jahre-Hinweise aus stabilen Isotopen. Ber. Sonderforschungsbereich 313, Univ. Kiel, 41, 106 pp.

Weinholz, P., 1987. FOCOS--eine Methode zum Zählen von Mikrofossilien mit Hilfe eines Personalcomputers. Ber. Sonderforschungsbereich 313, Univ. Kiel, 6: 5-16. 